\title{
Microeconomics and raw material price on capital structure adjustment through dynamic target in Indonesian textile industries
}

\author{
Sunita Dasman ${ }^{a^{*}}$, Erie Febriana ${ }^{\mathrm{a}}$, Sulaeman Nidar ${ }^{\mathrm{a}}$ and Aldrin Herwany ${ }^{\mathrm{a}}$
}

${ }^{a}$ Faculty of Economics and Busines, Universitas Padjadjaran, Indonesia

\begin{tabular}{l}
\hline C H R O N I C L E \\
\hline Article history: \\
Received: April 28, 2020 \\
Received in revised format: \\
July 30 2020 \\
Accepted: September 6, 2020 \\
Available online: \\
September 14, 2020 \\
\hline Keywords: \\
Adjustment speed \\
Company-specific \\
Dynamic capital structure \\
Macroeconomics \\
Raw material price
\end{tabular}

\section{A B S T R A C T}

This study aims to examine the effects of company-specific macroeconomic fluctuation in raw materials prices on the speed of adjustment through dynamic targeting capital structure on textile companies listed on the Indonesia Stock Exchange during 2012 and the second quarter of 2020. Using panel data regression of the fixed-effect method, we discovered that the speed of adjustment varies in each industry and period. Textile companies listed on the Indonesia Stock Exchange adjust their capital structure through a dynamic target of $53.3 \%$ per year. It takes 1 year and 10 months to close the target capital structure. The factors that determine the target capital structure include company size, tangibility, liquidity and growth opportunity, asset utilization, as well as retained earnings. On the other side, factors that contribute to the speed of adjustment include company size, growth opportunity, earnings volatility, asset utilization, retained earnings, distance to the target, and economic growth. Other factors that also affect the speed of adjustment include fluctuations in the prices of cotton and crude oil. The result of this study is expected to provide an optimal capital structure formulation to the textile industries in Indonesia to finance companies' operational activities and growth opportunities effectively. This study also provides an overview of how textile companies make capital structure adjustment, as there are changes in company-specific factors, macroeconomic conditions, and fluctuation in raw material prices.

\section{Introduction}

Based on the qualitative and quantitative criteria, the Ministry of Industry of Indonesia announced that the textile industry is one of the prioritized industry sectors that must be developed in the years of 2015-2035. The textile industry sector contributes $6,65 \%$ of gross domestic product (GDP) in 2015 with a total investment value of USD 3,16 trillion in 2015 , increasing by $49 \%$ from 2014. The textile export and textile product value also experienced an increase of $11.34 \%$ out of the total national export value of USD 12.32 billion in 2015. However, the growth rate of the textile industry experienced a decline of 6,58\% in 2013 , $1.53 \%$ in 2014, and -4,79\% in 2015 (Ministry of Industry of Indonesia, 2016). Consequently, it is important to look at the speed of adjustment of the textile industry in Indonesia under such conditions. As the free trade agreement officially took effect in 2005, an increase in the Indonesian textile exports by $11.34 \%$ in 2015 will have an impact on the increase of US Dollar rate accepted by companies as an international transaction currency. On the other hand, the company also needs US Dollar currency to purchase textile raw materials, such as cotton, that is imported from other countries such as Egypt and America. Therefore, how the textile industry in Indonesia makes capital structure adjustment to the Rupiah exchange rate against the US Dollar is * Corresponding author. E-mail address: sdasman@gmail.com (S. Dasman) 
worth examining. The textile and textile products (TPT) industry (ranging from the fiber manufacturing industry to the garment industry) requires raw materials, particularly cotton. Raw materials make up the biggest component in the cost structure by 56\%-58\% (Indonesian Textile Association, 2015), while energy consumption ranked second by $24 \%$ on the upstream industry (fiber manufacturing). On the contrary, energy consumption is very small in the downstream industry (garment). Such condition will affect the speed of adjustment for each industry. Therefore, the speed of adjustment of the textile industry towards fluctuations in raw material prices and fuel prices is worth examining. The government, as a regulator, also plays a role in determining company's capital structure through the interest rate setting policy (Jubaedah et al., 2016). Higher interest rates will inhibit the textile industry from obtaining debt funding. The company will seek other alternative financing sources such as equity. However, not all textile industries are listed on the Stock Exchange. Only 17 textile industries are listed and are still active on the Indonesia Stock Exchange, while companies need working capital for their operational activities. For that reason, we need to examine how the textile industry adjusts in response to interest rate volatility. Macroeconomics conditions and raw material price fluctuation may affect companies' capital structures. Companies need to adjust their capital structure to close the optimal conditions, depending on the access and availability of financial sources. We measure their ability to adjust the capital structure to optimal condition by adjustment speed. This study uses raw material price fluctuation for textile production, which was not included in previous research. This study examines how Indonesian textile companies adjust their capital structure when raw material price fluctuates.

\section{Literature review}

Adjustment speed measures the ability of companies to achieve their optimal capital structure. The ability of companies in adjusting their capital structures differs from one to another, depending on available financial sources, both internal and external financing. Based on previous studies, the internal sources may affect adjustment speed, e.g. company size, profitability, tangibility, liquidity, and company growth, while the external sources may affect the adjustment speed, including macroeconomic conditions, such as inflation, economic growth, interest rate, and exchange rate. Cotton fiber and crude oil for synthetic fiber are the two main raw materials in textile production. Those material's price fluctuations may affect the adjustment speed of the textile companies. In regards to company size, changes in capital structure involve high fixed costs. However, the cost is seen to be relatively small to large companies (Drobetz \& Wanzenried, 2006) and, therefore, large companies are faster to make adjustments. The adjustment costs are relatively lower than the small firm due to the less asymmetric information (Mahakud \& Mukherjee, 2011). Also, large companies have better access to financing sources from debts. That way, they can accelerate their adjustment.

In regards to profitability, an increase in profit may cause flexibility in the companies' financing sources. Profitability can serve as the source of internal funding in a form of a retained profit. The higher the profit of the firm, the more internal funding is available to the firm (Nor et al., 2011). Hence, profitability will slow down the adjustment speed. In regards to tangibility, companies' tangibility can serve as a guarantee to obtain funding from debts which reduces bankruptcy cost (Memon et al., 2015). The larger the value of the company's guarantee, the easier the company obtains funding from the debt. Hence, tangibility has a positive effect on the speed of adjustment. In regards to liquidity, the result of the previous studies has reported mix correlation between liquidity and leverage. Companies with cash flow are willing to use internal resources that support the pecking order theory. Furthermore, companies with high liquidity have a higher potential to repay debt financing liabilities, which reduces bankruptcy cost. These companies have a more significant tendency towards debt financing to reduce their financing cost by increasing debt-tax savings which support the trade-off theory (Kythreotis et al., 2018). Growing companies generally require more funding to grow their businesses. Because of that, these firms are highly dependent on external financing possibilities (Drobetz \& Wanzenried, 2006). They also have easy access to both equity or debt funding. Growing firms find it easier to change their capital structure by altering the composition of new issuance (Mahakud \& Mukherjee, 2011). Hence, the company's growth will accelerate capital structure adjustment. Earnings volatility measures the business risks that a company faces because of revenue uncertainty. Higher earnings volatility means higher business risk. According to the trade-off theory, companies prefer to avoid debt financing to avoid business risk. Therefore, companies prefer to maintain their existing capital structure. The higher the volatility, the higher the risk of financial distress that companies experience. The textile companies tend to not adjust their capital structure when earnings volatility is high. Asset utilization measures the efficiency of assets resulting from sales activities. In other words, the asset utilization ratio provides information on how efficient a company uses its assets to generate revenue and cash flow. The higher the ratio of asset utilization, the better the performance to generate revenue. Companies with high efficiency indicates that they are efficient in using assets to generate income. Retained earnings obtained by companies can reduce the use of corporate debt in companies' capital structure. Companies use retained earnings for operational activities, especially short-term operations. Retained earnings are a source of internal funding obtained from company profit which is not distributed to shareholders. Following the pecking order theory, companies prioritize internal funding to avoid bankruptcy costs. As a result, textile and garment companies do not use debt funds. Hence, retained earnings have a negative effect on the adjustment speed. 
In regards to distance to the target, the further the distance between the actual capital structure and target capital structure, the bigger the cost incurred to adjust it (Drobetz \& Wanzenried). The firm's cost of maintaining a sub-optimal debt ratio is higher than the cost of adjustment (Mahakud \& Mukherjee, 2011). Hence, the company will accelerate the adjustment process once the distance is getting further, to reduce higher adjustment costs. In regards to the inflation rate, investors demand more returns on their investments whenever the inflation rate increases. Issuing debt at a higher rate will increase the chances of bankruptcy. Therefore, the use of low leverage is suggested by the trade-off theory (Memon et al., 2015). This suggests the higher the inflation rate is, the higher the cost of debt, and the lower the use of debt is. If the inflation rate is high, the real value of tax deduction will also be high (Frank and Goyal, 2009). As a consequence, companies tend to use debt to gain benefits from the increasingly higher tax, according to the trade-off theory. Economic growth signs good economic conditions in a country. The positive trend of economic growth shows a lower possibility of a company to be bankrupt. These conditions create a possibility for the company to expand its capacity or business. Hence, companies tend to utilize debt financing during positive economic growth. According to the trade-off theory, companies prefer to have debt financing to get tax benefits. In regards to interest rate, investor demand more returns on their investments whenever the interest rate increases. The cost of capital becomes higher when the interest rate increase. Issuing debt at a higher rate increases the possibility of bankruptcy. Therefore, low leverage is suggested by the trade-off theory (Memon et al., 2015). Once the interest rate is high, the real value of tax deduction is also high (Frank \& Goyal, 2009). As a consequence, companies tend to use debt to gain benefits from the increasingly higher tax, according to the trade-off theory. In regards to the exchange rate, the increased Rupiah exchange rate against the US Dollar (Rupiah depreciation) benefits export-oriented or multinational companies. Those companies have more Rupiahs out of the increasing exchange rates. In this case, companies have more internal funding to adjust their capital structure. Therefore, companies use internal revenue in advance, according to the pecking order theory. In regards to the cotton price, cotton is one of the main materials in the textile industry. Cotton price fluctuation is a business risk that influences companies' earnings. Uncertainty arises from the difference between actual return and the excepted companies' return due to fluctuation in companies' earnings (Minton \& Schrand, 1999). According to the trade-off theory, high-risk firms experience increased debt-financing cost, hence companies do not have a high tendency towards using debt (Kythreotis et al., 2018). According to pecking order theory, for companies with high earning volatility, the risk of the inability of the company to repay annual interest and principal debt payments is more considerable (Kythreotis et al., 2018). In regards to the crude oil price, crude oil is the main material in synthetic fiber making and act as a raw material in the textile industry. The crude oil is also used as energy resources to fulfill world energy consumption. Indonesia is one of the crude oil producers in fulfilling world energy consumption. Higher crude oil price means higher earnings for crude oil producers, such as Indonesia, which is measured by the gross domestic product. On the other hand, crude oil price fluctuation also affects the existing companies' capital structure. Textile companies need to adjust their capital structure due to crude oil fluctuation. The capital structure adjustment depends on the availability and access to financing resources. Based on the trade-off theory, the company adjusts its capital structure to rely on debt financing to get tax benefits. According to the pecking order theory, the company prefers to utilize internal resources.

\section{Methodology}

To measure the speed of adjustment, we first mapped out the factors that determine changes in the target capital structure. A dynamic capital structure model serves as the function of factors that determine the target capital structure (Flannery \& Rangan, 2006). Companies that can adjust their capital structure at any time regardless of the costs of changes in capital structure will have their actual capital structure similar to the target capital structure. However, in reality, companies tend to fail in making adjustments to the target capital structure. This occurs when the adjustment cost is high or when the company's finance cannot meet it's financing needs. Changes in the capital structure among companies and periods are explained in the following equation (Hovakimian et al., 2001):

$$
\left(L V_{i, t}-L V_{i, t-1}\right)=\delta_{i, t}\left(L V_{i, t}^{*}-L V_{i, t-1}\right) \text { or } \quad L V_{i, t}=\left(1-\delta_{i, t}\right) L V_{i, t-1}+L V_{i, t}^{*}
$$

where:

$\delta_{\mathrm{i}, \mathrm{t}}=1-\left(1-\delta_{\mathrm{i}, \mathrm{t}}\right)$, speed of adjustment of company $\mathrm{i}$ at period $\mathrm{t}$

$\mathrm{LV}_{\mathrm{i}, \mathrm{t}}=$ capital structure of company $\mathrm{i}$ at period $\mathrm{t}$

$\mathrm{LV}_{\mathrm{i}, \mathrm{t}-1}=$ capital structure of company $\mathrm{i}$ at period $\mathrm{t}-1$

$\mathrm{LV}^{*} \mathrm{I}, \mathrm{t}=$ target capital structure of company $\mathrm{i}$ at period $\mathrm{t}$

\subsection{Target Capital Structure}

The target capital structure on Eq. (1) cannot be directly observed, but it can be estimated. Based on the model used in the previous research, the target capital structure is estimated with its determinants in the previous period (Banerjee, Heshmati \& Wihlborg, 2000) as in Eq. (2) as follows,

$$
L V^{*}{ }_{i, t}=\alpha_{0}+\alpha_{1} Z_{i, t-1}+\varepsilon_{i, t}
$$


where:

$\mathrm{LV}^{*}{ }_{\mathrm{i}, \mathrm{t}}=$ target capital structure for company $\mathrm{i}$ at period $\mathrm{t}$

$\alpha_{0} \quad=$ intercept

$\alpha_{1} \quad=$ regression coefficient

$\mathrm{Z}_{\mathrm{i}, \mathrm{t}-1}=$ variables which determine the target capital structure of company $\mathrm{i}$ at period $\mathrm{t}-1$

$\varepsilon_{\mathrm{i}, \mathrm{t}}=$ error

\subsection{Speed of Adjustment}

Upon estimating the target capital structure, the authors further estimated the speed of adjustment using company-specific variables and macroeconomic conditions as in the following Eq. (3). In 2016, Amjed and Shah conducted a study on the speed of adjustment on Pakistan's Non-Financial Industries listed on the Karachi Stock Exchange. They use macroeconomic variables, including the level of inflation and economic growth, interest rate, and banking sector performance. Their research findings reveal that the level of inflation and interest rate negatively affects the speed of adjustment, while economic growth positively affects the speed of adjustment.

$$
\delta_{i, t}=\beta_{0}+\beta_{1} Y_{i, t}+\mu_{i, t}
$$

where:

$\delta_{\mathrm{i}, \mathrm{t}}=1-\left(1-\delta_{\mathrm{i}, \mathrm{t}}\right)$, capital structure adjustment speed of company $\mathrm{i}$ at period $\mathrm{t}$

$\beta_{0} \quad=$ intercept

$\beta_{1} \quad=$ coefficient of regression

$\mathrm{Y}_{\mathrm{i}, \mathrm{t}}=$ variables affecting the speed of adjustment.

$\mu_{\mathrm{i}, \mathrm{t}}=$ error component

The samples in this research consist of companies from the textile industry sector registered on the Indonesia Stock Exchange from 2012 to 2020: Q2. The data were obtained from the census of manufacturing companies of the textile industry sub-sector. Based on the data completeness, we found that there are 12 textile companies out of 17 companies listed on the Indonesia Stock Exchange that meet our research requirements and are relevant to our research objectives. The sampling was conducted using a purposive sampling method with the samples selected based on the criteria and objectives of the research. The basis of sampling criteria is as follows: (a) textile companies that publish a complete financial report per quarter during this research period. (b) textile companies that are not experiencing bankruptcy. The variable and measurements in this study are presented in Table 1.

Table 1

The Variable and Measurement

\begin{tabular}{lcl}
\hline \multicolumn{1}{c}{ Variables } & Symbols & \\
\hline Company Size & SZ & Natural Logarithm from Total Assets \\
Profitability & PR & Profit After Tax divided by Total Assets \\
Tangibility & TN & Fixed Assets divided by Total Assets \\
Liquidity & LQ & Current Assets divided by Current Liabilities \\
Growth Opportunity & GO & Equity Market Value divided by Book Value \\
Retained Earnings & RE & Profit not share to investor divided by Total Asset \\
Earnings Volatility & EV & Absolute value of standard deviation of profitability \\
Asset Utilization & AU & Sales Revenue divided by Total Asset \\
Distance to The Target & DT & The distance between Target and Actual Leverage \\
Inflation Rate & IF & Quarterly Inflation Data \\
Exchange Rate & KR & Quarterly (USD/IDR) multiply by 10,000 \\
Cotton Price & CP & Quarterly Cotton Price (USD/KG) \\
Crude Oil Price & OP & Quarterly Crude Oil Price (USD/Barrel) \\
Capital Structure & LV & Total Debt divided by Total Asset \\
\hline
\end{tabular}

\section{Results and discussion}

Before the measurement of the speed of adjustment, it is necessary to firstly estimate the target capital structure by using company-specific factors from the previous period as in equation (2). Based on the theory and previous research findings, company-specific factors that affect target capital structure include company size, profitability, tangibility, liquidity, and growth opportunities.

Afterward, the authors estimated the speed of adjustment using company-specific factors as well as macroeconomic factors as in Eq. (3). The variables used to estimate the speed of adjustment include company size, profitability, tangibility, liquidity, and growth opportunities, distance to the target, inflation rate, Rupiah exchange rate, and cotton price. Descriptive statistics of the variables used in the research on textile industries are presented in Table 2. 
Table 2

Descriptive Statistic

\begin{tabular}{|c|c|c|c|c|c|}
\hline Variable & Observation & Mean & $\operatorname{Max}$ & Min & Std. Dev. \\
\hline Company Size & 519 & 18.7441 & 21.2276 & 16.6584 & 1.0928 \\
\hline Profitability & 519 & -0.0041 & 2.1811 & -0.3918 & 0.1061 \\
\hline Tangibility & 519 & 0.4960 & 0.9810 & 0.0010 & 0.1926 \\
\hline Liquidity & 519 & 1.7305 & 13.4024 & 0.0839 & 1.7583 \\
\hline Growth Opportunity & 519 & 2.6276 & 29.800 & 0.75 & 0.47 \\
\hline Earning volatility & 519 & 0.0276 & 2.1006 & 0.0000 & 0.0932 \\
\hline Asset utilization & 519 & 0.5127 & 2.0113 & 0.0000 & 0.3658 \\
\hline Retained Earnings & 519 & -0.0252 & 0.4336 & -9.8532 & 2.0601 \\
\hline Distance to The Target & 519 & 0.3264 & 0.8852 & 0.0014 & 0.2289 \\
\hline Inflation Rate & 519 & 4.50 & 8.40 & 1.96 & 2.02 \\
\hline Economic Growth & 519 & 5.03 & 5.81 & 2.97 & 2.02 \\
\hline Interest Rate & 519 & 6.89 & 8.86 & 4.66 & 1.09 \\
\hline Exchange Rate & 519 & 0.75 & 0.88 & 0.61 & 0.06 \\
\hline Cotton Price & 519 & 1.76 & 2.15 & 1.44 & 0.21 \\
\hline Crude Oil Price & 519 & 64.93 & 111.87 & 32.98 & 23.18 \\
\hline Capital Structure & 519 & 0.8641 & 0.99 & 5.25 & 0.06 \\
\hline
\end{tabular}

\subsection{Correlation Matrix}

The coefficient correlation among independent variables is as presented in Table 3. The coefficient correlation among the independent variable is not more than $(0.80)$. The highest coefficient correlation between profitability and liquidity is $(0.47)$. However, the value is smaller than (0.80). It means all independent variables are free from collinearity.

Table 3

Correlation Matrix of macroeconomic and raw material Variables

\begin{tabular}{|c|c|c|c|c|c|c|c|c|c|}
\hline $\begin{array}{l}\text { Independent } \\
\text { Variables }\end{array}$ & SZ & $\mathrm{RE}$ & DT & IF & EG & IR & KR & $\mathrm{CP}$ & OP \\
\hline $\mathrm{SZ}$ & 1 & & & & & & & & \\
\hline $\mathrm{RE}$ & -0.05 & 1 & & & & & & & \\
\hline DT & 0.28 & -0.25 & 1 & & & & & & \\
\hline IF & -0.03 & 0.08 & -0.07 & 1 & & & & & \\
\hline EG & -0.05 & 0.08 & -0.06 & 0.32 & 1 & & & & \\
\hline IR & 0.03 & 0.01 & -0.02 & 0.30 & -0.18 & 1 & & & \\
\hline KR & -0.07 & 0.09 & -0.08 & 0.39 & 0.76 & -0.33 & 1 & & \\
\hline CP & -0.02 & 0.04 & -0.03 & 0.10 & 0.54 & -0.02 & 0.36 & 1 & \\
\hline OP & -0.06 & 0.08 & -0.07 & 0.49 & 0.74 & -0.08 & 0.76 & 0.64 & 1 \\
\hline
\end{tabular}

\subsection{Target Capital Structure}

Based on Eq. (2), the estimation of the target capital structure uses the common effect, fixed effect, and random effect model. Chow test shows chi-square probability (0.0000) and Hausman test (0.0000). Based on the Chow test and the Hausman test report, the fixed-effect model is the best model to use in estimating the target capital structure. Table 4 reports panel data regression using fixed-effect methods. The company size, tangibility, liquidity, growth opportunity, asset utilization, and retained earnings are the determining factors of the target capital structure. The value of R-square shows that 0.9837 or $98 \%$ of the target capital structure is influenced by the five variables above, while the remaining $2 \%$ is influenced by other variables outside of the scope of this study. The result of R-square is high, indicating the model fits the probability value far below $(\alpha=$ $0.05)$.

\section{Table 4}

Determining Target Capital Structure

\begin{tabular}{|c|c|c|c|}
\hline Independent Variable & Coefficient & t-statistic & p-value \\
\hline Company Size & 0.3196 & 13.7857 & 0.0000 \\
\hline Profitability & 0.0356 & 0.3366 & 0.7366 \\
\hline Tangibility & -0.1841 & -2.0837 & 0.0377 \\
\hline Liquidity & -0.0198 & -3.5333 & 0.0004 \\
\hline Growth Opportunity & -0.0068 & -1.8748 & 0.0614 \\
\hline Earnings Volatility & 0.0303 & 0.2599 & 0.7951 \\
\hline Asset Utilization & 0.0596 & 2.8166 & 0.0050 \\
\hline Retained Earnings & -0.3701 & -32.1762 & 0.0000 \\
\hline
\end{tabular}




\subsection{The Speed of Adjustment}

Based on the chi-square probability on the Chow test (0.0000) and Hausman test $(0.0000)$, it can be concluded that the fixed effect is the right instrument for hypotheses testing. Table 5 below presents the calculation result of the variables affecting capital structure adjustment speed. The company-specific variables used in this study include company size, profitability, tangibility, and liquidity, company's growth, earnings volatility, asset utilization, and retained earnings, while the variables of macroeconomic volatility used in this study include the distance to the target, inflation rate, economic growth, interest rate, and exchange rate. In this study, the authors also use the variables of textile raw materials fluctuation in cotton and crude oil prices. The value of R-square showed 0.9459 , which means $94 \%$ of adjustment speed is influenced by the variables used in the model.

\section{Table 5}

Speed of Adjustment

\begin{tabular}{|c|c|c|c|c|c|c|c|}
\hline Independent Variable & Coefficient & t-statistic & Probability & Independent & Coefficient & t-statistic & Probability \\
\hline Company Size & 0.0556 & 3.5872 & 0.0004 & Distance to & -1.0825 & -23.7412 & 0.0000 \\
\hline Profitability & -0.0912 & -1.3766 & 0.1693 & Inflation & -0.3712 & -1.3921 & 0.1645 \\
\hline Tangibility & -0.0233 & -0.4221 & 0.6732 & Economic & 0.0233 & 2.1369 & 0.0331 \\
\hline Liquidity & -0.0026 & -0.7290 & 0.4664 & Interest Rate & 0.0060 & 1.5790 & 0.1150 \\
\hline Growth Opportunity & -0.0060 & -2.5862 & 0.0100 & Exchange & 0.0348 & 0.5208 & 0.6027 \\
\hline Earnings Volatility & 0.1386 & 1.8981 & 0.0583 & Cotton price & 0.0474 & 1.7979 & 0.0728 \\
\hline Asset Utilization & 0.0265 & 1.9102 & 0.0567 & Crude Oil & -0.0010 & -3.2877 & 0.0011 \\
\hline Retained Earnings & -0.0645 & -6.5450 & 0.0000 & & & & \\
\hline
\end{tabular}

The result of the t-test for company size on the speed of adjustment is 3.5872 with a probability value of 0.0004 , less than $(\alpha<$ 0.05). Large companies have more flexibility to change their capital structure compared to small companies. If a change in the capital structure involves a high fixed cost, this cost is relatively small for large companies. Therefore, large companies are faster to correct deviation from the target capital structure. Besides, large companies have more transparent and publicly available information and analysis coverage (Drobetz \& Wanzenried, 2006). Large companies have better access to debt or equity financing sources to adjust their capital structure. Textile companies tend to finance with debt to adjust their capital structure to get tax benefits, according to the trade-off theory. The result of the t-test for profitability towards the speed of adjustment is $(-1.3766)$, with a probability value of 0.1693 , higher than $(\alpha>0.05)$. Increased profitability can boost financing sources flexibility to change the capital structure (Mahakud \& Mukherjee, 2010). Profitability can serve as the source of internal funding if it turns into a retained profit. It is in line with the pecking order theory. The average profitability in textile companies is $(-0.01)$ or minus $1 \%$ of the total asset, with a standard deviation of $3 \%$. It means Indonesian textile companies tend to minimize profit management and maintain existing capital structure when there is a change in profitability. The results of this study are not consistent with the previous research findings conducted by Elsas and Florysiak (2010), Mahakud and Mukerjee (2011), Oztekin and Flannery (2011), Nor et al. (2011) and Memon et al. (2015).

The result of the t-test for tangibility towards the speed of adjustment is (-0.4221), with a probability value of 0.4 , which is higher than $(\alpha>0.05)$. According to Haas and Peeters (2004), tangibility affects the speed of adjustment in two ways, depending on its types of fixed assets. Some fixed assets are company liquid specific factors, such as certain machines and transportation equipment. Companies generally prefer internal funding and/or long-term debt. If a company uses long-term debt funding, it will cause a positive relationship between tangibility and the speed of adjustment. The textile companies tend to maintain existing capital structure when there is a change in tangibility. According to the Indonesia Textile Association, Indonesia textile machinery is obsolete and specific. In addition to that, Indonesian textile companies have an average tangibility of $0.5(50 \%$ of the total asset) with a standard deviation of $4 \%$, meaning that there is no significant investment in Indonesia textile companies. In this case, companies' tangible assets cannot be used as collateral to get debt financing. Therefore, the companies do not adjust their capital structure during changing tangible assets. The results of this study are not consistent with the previous research findings conducted by Mahakud and Mukherjee (2011) and Etudaiye-Muhtar and Ahmad (2015). The result of the t-test for liquidity towards the speed of adjustment is $(-0.7290)$, with a probability value of 0.4664 , which is higher than $(\alpha>0.05)$. Liquidity measures a company's ability to fulfill its current liabilities. Higher liquidity will increase their ability to source both equity and debt financing. Besides, the company uses debt financing to reduce agency problems between managers and principals (Jensen \& Meckling, 1976). Based on the trade-off theory, companies will use debt financing to get tax benefits. The use of current debt financing can reduce liquidity in general, but increase long-term debt. Indonesian textile companies tend to remain at the existing capital structure during a liquidity change. The results of this study are not consistent with the previous research findings conducted by Oztekin and Flannery (2012) and Wolmarans et al. (2013). The result of the t-test for the company's growth to the speed of adjustment is (-2.5862), with a probability value of 0.0100 , which is lower than $(\alpha<0.05)$. Growing companies find it easier to manage their capital structure by changing the composition of external financing based on the target capital structure due to the positive impact of future growth opportunities. Therefore, growing companies can obtain funding from debt or equity. This is exactly in line with the trade-off theory, in which growing companies tend to avoid debt 
financing due to high risk. The results of this study strengthen previous findings of Mahakud \& Mukherjee (2010); Memon, Rus \& Ghazali (2015), and Etudaiye-Muhtar \& Ahmad (2015). The result of the t-test for earnings volatility to the speed of adjustment is (1.8981), with a probability value of 0.0583 , which is lower than $(\alpha<0.1)$. Higher earnings volatility means higher business risk. According to the trade-off theory, companies prefer to avoid debt financing to avoid business risks. On the other hand, the use of debt financing will create tax benefits. For this reason, textile companies prefer to adjust their capital structure by debt financing to get tax benefits. The result of the t-test for asset utilization to the speed of adjustment is (1.9102), with a probability value of 0.0567 , which is lower than $(\alpha<0.1)$. Asset utilization measures the efficiency of assets resulting from sales activities. The higher the ratio of asset utilization, the better the performance in generating revenue. Companies with high efficiency indicate they are efficient in using assets to generate income. The textile companies tend to utilize debt financing to adjust their capital structure to get more tax benefits, according to the trade-off theory. The result of the t-test for retained earnings to the speed of adjustment is $(-6.5450)$, with a probability value of 0.0000 , which is lower than $(\alpha<0.01)$. Retained earnings obtained by companies can reduce the use of corporate debt in companies' capital structure. Companies use retained earnings for operational activities, especially short-term operations. Retained earnings are a source of internal funding obtained from company profit, which is not distributed to the shareholders. Following the pecking order theory, companies prioritize internal funding to avoid bankruptcy costs. As a result, the use of debt funds is not carried out by textile and garment companies. For this reason, retained earnings negatively affect the adjustment speed. This finding is consistent with the findings of Getzmann et al. (2015). The results of the t-test for the distance between the actual capital structure and the target capital structure towards the speed of adjustment is (-23.7412), with a probability value of 0.0000 , which is lower than $(\alpha<0.01)$. The results support the opinion which states that the narrower the distance between the actual capital structure and the target capital structure of the company, the faster the company adjusts (Nor et al., 2015). These results also imply that companies accelerate the adjustments as there are several benefits for being on the condition of the target capital structure, according to the trade-off theory. This finding is consistent with the findings of the research conducted by De Haas and Peeters (2006); Drobetz and Wanzenried (2006); Mahakud and Mukherjee (2011) and Amjed and Shah (2016).

The result of the t-test for the inflation rate to the speed of adjustment is (-1.3921), with a probability value of 0.1645 , which is higher than $(\alpha>0.05)$. When the inflation rate is high, the company's ability to pay the debt declines. Investors also require higher returns during the inflation period to reduce their risk. As a consequence, companies tend to keep their current capital structure. This finding is consistent with the findings of Amjed and Shah (2016). The result of the t-test for the economic growth rate to the speed of adjustment is (2.1369), with a probability value of 0.0331 , which is lower than $(\alpha<0.05)$. Economic growth is a sign of good economic conditions in a country. The positive trend of economic growth shows a lower possibility of a company going bankrupt. These conditions create a possibility for companies to expand their capacity or business. Textile companies tend to utilize debt financing during positive economic growth. According to the trade-off theory, companies prefer to have debt financing to get tax benefits. Therefore, textile companies adjust their capital structure by adding debt financing to get more tax benefits. The result of the t-test for the interest rate to the speed of adjustment is (1.5790), with a probability value of 0.1150 , which is higher than $(\alpha>0.05)$. Investors demand more return on their investments whenever the interest rate increases. The cost of capital becomes higher when the interest rate increases. Issuing debt at a higher rate causes the possibility of bankruptcy to increase. The textile companies prefer to maintain the existing capital structure due to the higher cost of capital when the interest rate is high. The result of the t-test for the Rupiah exchange rate against the US Dollar towards the speed of adjustment is $(0.5208)$, with a probability value of 0.6027 , which is higher than $(\alpha>0.05)$. Weaker Rupiah exchange rate against the US Dollar would benefit export-oriented or multinational companies. On the other hand, those companies are also expected to pay more Indonesian Rupiahs when the exchange rate gets weaker, especially the raw material imported. For this reason, the textile companies prefer to maintain the existing capital structure. The result of the t-test for cotton price towards the speed of adjustment is (1.7979), with a probability value of 0.0728 , which is smaller than $(\alpha<0.10)$. Cotton is one of the main raw textile materials that is imported from other countries, such as America, Egypt, India, and China. The company's capital structure is influenced by the fluctuation of cotton prices. Higher cotton price means a higher cost of capital. Cotton prices are be booked in advance to obtain raw material in textile production. Indonesia textile companies tend to use debt financing during cotton price increase to get more tax benefits. Therefore, the Indonesian textile companies adjust their capital structure when cotton price increases. The result of the t-test for crude oil price towards the speed of adjustment is $(-3.2877)$, with a probability value of 0.0011 , which is smaller than $(\alpha<0.05)$. Crude oil is one of the main raw textile materials for synthetic fiber. Indonesia is one of the crude oil producers, making the raw material available anytime. Besides, crude oil also is used as energy resources that are required to be available at any time for running production. Therefore, the textile companies tend to adjust their capital structure using internal financing when crude oil price increase, according to the pecking order theory.

\section{Conclusion}

Having analyzed the effects of company-specific factors, macroeconomic conditions, and textile raw materials on the speed of adjustment, we can conclude that the speed of adjustment is heavily influenced by the determination of a target capital structure. The dominant factors that affect the target capital structure possibly differ from one type of industry to another, but the dominant factors of the target capital structure in the textile industry include company size, tangibility, liquidity, growth opportunity, asset 
utilization, and retained earnings. The speed of adjustment in the textile industry highly varies as a response to changes in company-specific factors, macroeconomic conditions and raw material price to the target capital structure. Capital structure adjustment speed of the textile industry in Indonesia is at an average of $53.3 \%$ per year, or it may take about 1 year 10 months to narrow down the gap of capital structure adjustment. Based on our findings, the factors that consistently affect the speed of adjustment include company size, growth opportunity, earnings volatility, asset utilization, retained earnings, distance to the target capital structure, economic growth, cotton price, and crude oil price. This research shows that raw material price fluctuation affects the adjustment of capital structure. Unfortunately, cotton as one of the main raw textile materials is not suitable to grow in the Indonesian climate. Cotton has to be imported from other countries to support the running of textile production. Cotton price increases mean a higher cost of capital. In addition to that, cotton that has to be imported from other countries tend to take a longer time. The results of this study may be used as a reference for future research with bigger samples and units of analysis, such as textile industries across Southeast Asia in particular, and Asia in general, as textile manufacturers. Further research can be conducted using other variables in the determination of adjustment speed, such as coal price, which is one of the highest energies consumed in Indonesian textile production. In addition to that, labor costs also have a big portion in cost structure, especially in garment manufacturers.

\section{References}

Amjed, S., \& Shah, S. A. (2016). The impact of volatile economic conditions on corporate capital structure adjustment towards dynamic target in Pakistan. Pakistan Journal of Commerce and Social Sciences (PJCSS), 10(2), 296-315.

Banerjee, S., Heshmati, A., \& Wihlborg, C. (2000). The Dynamics of Capital Structure. SSE/EF/ Working Paper Series in Economics and Finance No. 333, Stockholm: Stockholm School of Economics.

De Haas, R., \& Peeters, M. (2006). The dynamic adjustment towards target capital structures of firms in transition economies. Economics of Transition, 14(1), 133-169.

Drobetz, W., \& Wanzenried, G. (2006). What determines the speed of adjustment to the target capital structure?. Applied Financial Economics, 16(13), 941-958.

Elsas, R., \& Florysiak, D. (2015). Dynamic capital structure adjustment and the impact of fractional dependent variables. Journal of Financial and Quantitative Analysis, 50(5), 1105-1133.

Etudaiye-Muhtar, O. F., \& Ahmad, R. (2015). Empirical evidence of target leverage, adjustment costs and adjustment speed of non-financial firms in selected African countries. International Journal of Economics and Financial Issues, 5(2), $482-488$.

Flannery, M. J., \& Rangan, K. P. (2006). Partial adjustment toward target capital structures. Journal of Financial Economics, 79(3), 469-506.

Frank, M. Z., \& Goyal, V. K. (2003). Testing the pecking order theory of capital structure. Journal of Financial Economics, $67(2), 217-248$.

Hovakimian, A., Opler, T., \& Titman, S. (2001). The debt-equity choice. Journal of Financial and Quantitative analysis, 36(1), $1-24$.

Jensen, M. C., \& Meckling, W. H. (1976). Theory of the firm: Managerial behavior, agency costs and ownership structure. Journal of Financial Economics, 3(4), 305-360.

Jubaedah, J., Yulivan, I., \& Hadi, A. R. A. (2016). The Influence of Financial Performance, Capital Structure and Macroeconomic Factors on Firm's Value-Evidence from Textile Companies at Indonesia Stock Exchange. Applied Finance and Accounting, 2(2), 18-29.

Kythreotis, A., Nouri, B. A., \& Soltani, M. (2018). Determinants of capital structure and speed of adjustment: Evidence from Iran and Australia. International Journal of Business Administration, 9(1), 88-113.

Mahakud, J., \& Mukherjee, S. (2011, February). Determinants of adjustment speed to target capital structure: Evidence from Indian manufacturing firms. International Conference on Economics and Finance Research, 4, 67-71.

Memon, P. A., Rus, R.B.M., \& Ghazali, Z.B. (2015). Dynamism of capital structure: Evidence from Pakistan. Journal of International Business and Economics, 3(1), 52-63

Minton, B., \& Schrand, C. (1999). The impact of cash flow volatility on discretionary investment and the cost of debt and equity financing. Journal of Financial Economics, 54(3), 423-460.

Nor, F. M., Haron, R., Ibrahim, K., Ibrahim, I., \& Alias, N. (2011). Determinants of target capital structure: Evidence on south east Asia countries. Journal of Business and Policy Research, 6(3), 39-61.

Wolmarans, H., Moyo, V., \& Brummer, L. (2013). Dynamic capital structure determinants: Some evidence from South African firms. Journal of Economic and Financial Sciences, 6(3), 661-682.

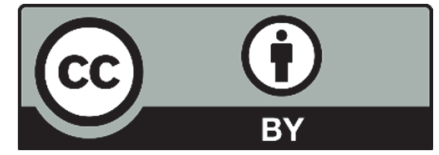

(C) 2020 by the authors; licensee Growing Science, Canada. This is an open access article distributed under the terms and conditions of the Creative Commons Attribution (CC-BY) license (http://creativecommons.org/licenses/by/4.0/). 